FABULARIO 



\section{Habitar el relámpago: paisajes ominosos}

\section{Por Juan Manuel Roca ${ }^{1}$}

Creo que la reserva que tuvo Gombrowicz acerca de la poesía que busca a todo trance ser "poética" ha hecho por fortuna blanco en algunos autores que huyen de los tópicos líricos, más cercanos como están a Lautreamont que a Bécquer, más a la distopía que vivimos que al gorjeo del ruiseñor. Hemos aprendido a valorar a quienes saben apuntar con tino al público burgués para arrojarle más tomates que rosas. Y a quienes no propiamente lo hacen con alardes vanguardistas ya marchitos, con manifiestos escritos antes de realizar una obra, como quien dice, con los gestos vanos de querer poner la huella antes de dar el paso.

Pienso esto al leer los poemas de Norman Paba, unos poemas que parecen nuestro reflejo colectivo visto en un espejo cóncavo. Lo suyo, me parece, es un cambio de dominio de la poesía sumisa, que habla por hablar, al dominio de una poesía que rehúye el manierismo, contraria a la que se escribe en estos pagos con bastante frecuencia. Hay contadas excepciones que no encajan en lo que afirmo, un tono homogéneo que permite insertar versos de un poeta en los versos de otro poeta sin que se altere para nada ni el sonido ni el sentido.

Frente a una artillería de mentiras y miedos que llega inclusive a domesticar la poesía, a hacerla cortesana y obediente, la palabra de Paba resulta inquietante, porque no es tremendista, sino sucia de realidad, sin que sea por esto realista.

El poeta le sigue en estos seis poemas un prontuario a nuestro entorno. Y anota sus desvaríos: el de quienes pierden "la cabeza por amor una y otra vez" o cohabitan con la soledad o con la ebriedad en un país más ebrio aún. Un país dónde no pocos preguntan dónde queda su casa, dónde queda la vida. Todo podría resultar en extremo

\footnotetext{
${ }^{1}$ Juan Manuel Roca, poeta colombiano, nacido en Medellín en 1946. Ha publicado diversos poemarios, entre los que pueden citarse Lugar de apariciones (2000), Un violín para Chagall (2003) y Tres caras de la luna (2013). Durante más de una década dirigió el Magazín Dominical de El Espectador y actualmente se encarga de la línea de "Poesía" en la Maestría en Escrituras Creativas de la Universidad Nacional de Colombia (Bogotá). Premio Nacional de Poesía Eduardo Cote Lamus (1975), Premio Nacional de Periodismo Simón Bolívar (1993) y Premio Casa de las Américas, Poesía (2007), entre otros.
} 
dramático, pero la forma que tiene de expresarlo lo aleja del gimoteo, como si dijera entre líneas que la soberbia colectiva a veces puede desalojar los pequeños dramas del individuo.

Frente a la jauría de los miedos, miedo al otro, miedo a la noche, miedo a sí mismo, miedo a la incertidumbre, miedo a perder el más adocenado empleo; frente a los miedos en los que somos atrapados como reos, su palabra habla del sueño, y el sueño no es verbal, pero habla más aún del maldormir en callejones, de dormir con quienes ingieren grajeas de expiación, de dormir en un auto oxidado, de "dormir esposado en estaciones de policía o en bibliotecas", "en taxis que regresan a ningún lugar". Pero también es bueno hacerlo bajo bengalas en ultramar "escuchando la conversación subterránea de todas las cosas vivas".

Su poética contiene una suerte de almacén de símbolos (la expresión es de Baudelaire), de imágenes que nos acompañan y siguen inquietándonos tras su lectura.

Su alucinada y/o alucinante versión de San Victorino, de un paisaje del Bosco que hace itinerancia en nuestra ciudad, de nuevo nos recuerda que, entre la realidad y el deseo, en esta geopatía, en esta enfermedad del paisaje de una multitud que vomita (salud, García Lorca), la poesía que no escamotea su acoso siempre tiene una relación disfuncional con la falsa realidad.

Paba ve la belleza escondida en el harapo, como algunos ángeles de su admirado Caravaggio. Él es uno y otros. Es Chet Baker levantando la trompeta resurrecta tras su muerte en Ámsterdam, un lírico del jazz que regresa del olvido para ponerle la banda sonora a esta ciudad que nunca conoció.

Paba es o quiso o pudo ser "un monje salvaje"; puede ser, en fin, el intento por despojarse de un yo atenazante, un paseante que decide "lanzarse a las vías de un tren que no existe".

Yo agregaría que por fortuna ese tren luctuoso no existe y que, de existir, Norman lo encontraría posiblemente en las carrileras de un cuento de Arreola, a lo mejor con un guardagujas de su misma inusitada imaginería. 